\title{
Efficacy of anti-oxidants when used for distinctive time to re-establish bond strength
}

\author{
Princy Maria Philip ${ }^{1}$, Sindhu J., ${ }^{2, *}$, Mohan Thomas Nainan ${ }^{3}$ \\ ${ }^{1}$ PG Student, ${ }^{2}$ Reader, ${ }^{3}$ Professor \& HOD, Dept. of Conservative and Endodontics \\ *Corresponding Author: \\ Email: drsindhuj@yahoo.co.in
}

\begin{abstract}
Introduction: The objective was to evaluate the effect of three antioxidants Sodium thiosulphate, Sodium ascorbate and Rosemarinic acid with different application times in reversing the bond strength of dentine compromised by sodium hypochlorite $(\mathrm{NaOCl})$ and EDTA.

Material and Method: Crowns of bovine incisors were cut to expose the dentine pulp chamber from which 84 (buccal and lingual surface) samples were selected. The specimens were polished and randomly distributed into 6 groups. Each group has $\mathrm{n}=7$ i.e 6 X 7= 42 samples. Group 1:0.9\% sodium chloride for 30mins (negative control), Group 2: 5.25\% $\mathrm{NaOCl}$ for $30 \mathrm{mins}, 17 \%$ EDTA for 3 mins and $5.25 \% \mathrm{NaOCl}$ for $1 \mathrm{~min}$ (positive control). Groups (3, 4, 5 and 6) were treated in the same manner as positive control. Group 3 samples were neutralized by immersion in an inert solution (saline) for 10mins. The samples of Groups 4, 5, 6 were neutralized with the antioxidant reagents mentioned above. Group 4, 5, 6 were sub-grouped for 3 mins, $5 \mathrm{mins}$ and 10 mins i.e $4 a, 4 b, 4 c 5 a, 5 b, 5 c$ and $6 a, 6 b, 6 c$. The specimens were dried and etched with total adhesive system according to manufactures instructions. Followed by $3 \mathrm{~mm}$ build-up of composite resin incrementally to bonded dentine and light cured for 20 seconds. The micro tensile bond strength was determined using universal testing machine and was statistically analysed with independent sample t-Test with $95 \%$ confidence limits.

Results: At 3 mins and 5mins rosemary extract performed better than sodium thiosulphate and sodium ascorbate (with P values: $0.000,0.000$ and $0.000,0.040)$. Rosemary extract when used for $3 \mathrm{mins}$ and 5 mins showed a significantly better performance than at $10 \mathrm{mins}$ (with $\mathrm{P}$ values 0.000 and 0.001 ). At 3 mins and $5 \mathrm{mins}$ rosemary did not show any significant difference.
\end{abstract}

Keywords: Sodium Thiosulphate, Sodium Ascorbate, Rosemarinic acid, Sodium hypochlorite.

\section{Introduction}

One of the main objectives of endodontic therapy is to decrease the microbial load and to facilitate periapical healing \& prevent reinfection. Bacteria and their products are regarded as the major cause of pulp and peri-radicular diseases. ${ }^{1,2}$ The complex anatomy of root canal spaces and use of various instrumentation techniques alone do not help in achieving the objective of endodontic therapy. This leads to the emphasis on chemical means of cleaning and disinfection of the root canal system.

Among the chemical irrigants sodium hypochlorite is widely and routinely used for endodontic therapy due to its anti-bacterial and organic dissolution properties ${ }^{3}$ in a concentration ranging from $0.5 \%-5.25 \%{ }^{4}$ but the adverse effect on the resin-dentine bond strength have been previously investigated and confirmed.

An antioxidant is a molecule that inhibits the oxidation of other molecules and terminates the chain reaction such as Beta-carotene, Vitamin E, Thiols or Ascorbic acid (vitamin C). Hence the compromised bond strength could be restored by the application of an antioxidant solution before adhesive procedure, resulting in neutralization and reversal of the oxidizing effect of $\mathrm{NaOCl}$ of dentine surface. ${ }^{5,6}$

Sodium thiosulphate an anti-oxidant has been used in medicine and as a neutralizing agent of $\mathrm{NaOCl}$ in microbiological analysis, showing potential to be used as a reducing agent for $\mathrm{NaOCl}$-treated dentine without damaging biological tissues. ${ }^{7-9}$

Ascorbic acid and its sodium salts are well known antioxidants that are capable of reducing variety of oxidative compounds especially free radicals, ${ }^{10,11}$ in other words it promotes polymerization reaction of free radicals of the adhesive agent without premature termination and reverses the disrupted bonding to $\mathrm{NaOCl}$-treated dentine. ${ }^{5}$

Rosemarinic acid (RA) extracted from rosemary a polyphenol; P-toluene sulfinic acid sodium salt has shown to accelerate the polymerization of composite resin. It has a strong free radical scavenging activity and is a MMP inihibitor. ${ }^{6}$

These antioxidants could reverse the compromising effect of $\mathrm{NaOCl}$ on bond strength of enamel and dentine by restoring the altered redox potential of the oxidized bonding substrate. ${ }^{10,11,6,12,17}$

This study aims to determine the effectiveness of anti-oxidants a). Sodium thiosulphate (ST), (b). Sodium ascorbate (SA) and (c). Rosemary extracts (RE) to restore bond strengths when used for different time intervals.

The null hypothesis tested was that neither the application time nor the type of antioxidant/reducing agent has any effect on reversing compromised bonding to $\mathrm{NaOCl}$ treated dentine. 


\section{Materials and Methods}

Specimen Preparation: Eighty-four extracted incisors, stored in $0.2 \%$ thymol was used in this study. ${ }^{10}$ The crowns were sectioned buccally on the middle third to expose the dentine area $3-5 \mathrm{~mm}$ of the incisal portion were removed horizontally with a double-sided diamond disc under running water. The dentin area was penetrated by the disc longitudinally, a $10 \mathrm{~mm}$ buccal section was made from the incisal edge perpendicular to the long axis of the tooth. Then the pulp tissue was carefully extracted with a spoon excavator. ${ }^{13}$ The resulting slabs of the intracoronal dentin were flattened and polished with 180-grit and 600-grit SiC papers under running water for 30 seconds to standardize the smear layer of the dentin surface.

The specimens were randomly distributed into 6 groups according to the chemical irrigant used as in Table 1.

Material information for endodontic irrigation:

\begin{tabular}{|l|l|}
\hline \multicolumn{1}{|c|}{ Endodontic Material } & \multicolumn{1}{c|}{ Concentration } \\
\hline $\begin{array}{l}\text { Sodium hypochlorite (Hypochlorite } \\
\text { SPEIKO) }\end{array}$ & $5.25 \% \mathrm{NaOCl}$ \\
\hline $\begin{array}{l}\text { Sodium Ascorbate 500mg (eq. to } \\
\text { ascorbic acid 400mg) manufactured by } \\
\text { Abbott healthcare pvt. Ltd. }\end{array}$ & $\begin{array}{l}10 \% \text { Sodium Ascorbate/ } \\
\text { Neutral Ascorbic acid }\end{array}$ \\
\hline Sodium thio-sulphate & $5 \%$ Sodium thiosulphate \\
\hline Rosemarinic acid & $6 \%$ Rosemarinic acid \\
\hline
\end{tabular}

Bonding Procedure: All specimens were dried with absorbent papers before the bonding procedures, etched with $37 \%$ phosphoric acid (N- Etch, Ivoclar Vivadent, India) for 20 second and a total etching adhesive system (Kerr OptiBond S, United States) was applied to the surface of the pulp chamber dentine. Three layers with $1 \mathrm{~mm}$ of increment of resin composite (Kerr Herculite Precise Kit, United States) was added to the bonded dentine ${ }^{14}$ and each was light cured for 20 seconds. After the restoration, the blocks were stored in distilled water at $37^{\circ} \mathrm{C}$ for $24 \mathrm{hrs}$.

Micro- Tensile Bond Strength: 24 hrs later, the blocks from each group were removed from water, dried and fixed to an acrylic plate to permit creation of serial cross-sections by using a diamond saw (Isomet; Buehler Lake Bluff, IL) operating at $300 \mathrm{rpm}$. Rectangular slabs $(4 \mathrm{cmX} 3 \mathrm{~cm} \mathrm{X} 4 \mathrm{~cm})$ were made from the central crown segment to obtain a linear resin/dentine interface. Each slab was submitted to tensile load individually in a universal testing machine $^{14}$ (UTM- EZ-Test; Shimadzu Co, Kyoto, Japan) at a crosshead speed of $1 \mathrm{~mm} / \mathrm{min}$ until fracture.

The micro tensile bond strength was then determined and analyzed using independent sample tTest with confidence limits for inter and intra group comparison by the Statistical software namely SAS 9.2, SPSS 15.0, Stata 10.1, Medical 9.0.1, Systat 12.0 and R environment ver.2.11.1.

\section{Results}

The micro tensile bond strength values for means and standard deviations are shown in the Table 2, 3 and 4. Statistical analysis revealed that there were significant differences between all the groups while Group $2(\mathrm{NaOCl}+$ EDTA) showed least bond strength showed to pulp chamber dentine $(\mathrm{P} \leq 0.05)$.
3 and 5 mins application of rosemary extract significantly increased the micro tensile bond strength to $\mathrm{NaOCl}$ treated dentine compared to sodium thiosulphate and sodium ascorbate groups. Rosemary extract showed a significant better performance at 3 and 5 mins than at 10 mins. Sodium ascorbate performed better than sodium thiosulphate at 3 and 5 mins. At 10 mins there was no significant difference among the experimental groups.

\section{Discussion}

In this study, $\mathrm{NaOCl}$ was used as an irrigant in all the groups. $\mathrm{NaOCl}$ is widely used irrigant during endodontic treatment due to its capacity to dissolve organic tissues and its antibacterial effects. ${ }^{6,15}$ This study found out that $\mathrm{NaOCl}$ decreases the bond strength between the dentine and composite resins. This results in accordance with many previous studies. ${ }^{15,16}$ This is due to the reactive residual free-radicals released by the oxidizing effect of $\mathrm{NaOCl}$, which hinder the polymerization of dental adhesive system.

Some researchers have shown that application of reducing agents/anti-oxidants before the adhesive procedures can interact with $\mathrm{NaOCl}$ by-products and neutralize the oxidizing effect of $\mathrm{NaOCl}$ - treated dentine surface. ${ }^{17,5}$ Recently, the use of anti-oxidants / reducing agents has been increased before the adhesive procedures to increase the bond to dentine and to decrease micro-leakage. ${ }^{6,17-20}$ In addition, reducing agents are now-a-days frequently used as polymerization facilitating ${ }^{21}$ agents and cross-linkers. The three main antioxidant mechanisms are chelation to metals, quenching free radicals and chain breaking of the free radicals. ${ }^{22}$ Antioxidants are synthetically produced but some are derived from natural sources and their natural extracts.

In this study, the application of rosemary extract to $\mathrm{NaOCl}$ treated dentine significantly increased bond 
strength with application times of 3 mins and 5 mins. Rosemarinic acid which is extracted from rosemary is a polyphenol and the best antioxidant activity of 72 species/herbs. ${ }^{23,24}$ The antioxidant activity of rosemarinic acid is due to the ability of catechol to form an intermolecular hydrogen bond between the free hydrogen of its hydroxyl and phenoxyl radicals, thus improving the radical stability. ${ }^{25,26}$

Sodium ascorbate improves the bond strength via redox reaction on the treated substrate. It allows free radical polymerization of the adhesive to continue without premature termination and reverses the compromised bonding of the treated dentine. ${ }^{5}$ But the beneficial effect of sodium ascorbate mostly occurs within $1 \mathrm{~min}$ and also the reducing action of sodium ascorbate does not change with more concentration.

Sodium thiosulphate neutralizes the oxidizing agent, through the redox reaction and leads to optimal polymerization of the resin composite. But $3.5 \mathrm{ml}$ and more quantity of Sodium thiosulphate are required to neutralize $5 \%$ sodium hypochlorite ${ }^{27}$. This neutralization reaction also results in formation of yellow precipitates of sodium sulphate and sodium chlorides $^{28}$ and reducing the effect of sodium thiosulphate.

The antioxidant activity of the reducing agent and $\mathrm{NaOCl}$ treated dentine depends on their total antioxidant capacity value.

Polyphenols like Rosemarinic acid were shown to have higher total antioxidant capacity than sodium ascorbate and sodium thiosulphate. Also Rosemarinic acid has a MMP-inhibitor effect. MMP-activation leads to degradation of extra cellular matrix. ${ }^{6}$ So the use of MMP inhibitor promises to increase the durability of resin-dentin bonds.

\section{Table 1: Sample Division}

\begin{tabular}{|c|c|c|}
\hline $\begin{array}{c}\text { Negative Control } \\
\left(\begin{array}{c}\text { Nacl }) \\
(\mathbf{n}=7)\end{array}\right.\end{array}$ & $\begin{array}{c}\text { Positive Control } \\
(\mathbf{N a O C l + 1 7 \%} \text { EDTA }) \\
(\mathbf{n}=7)\end{array}$ & $\begin{array}{c}\text { Saline } \\
(\mathbf{N a O C l + 1 7 \%} \text { EDTA+Nacl }) \\
(\mathbf{n}=\mathbf{7})\end{array}$ \\
\hline group 1 $(\mathrm{n}=7)$ & group 2 $(\mathrm{n}=7)$ & group 3 $(\mathrm{n}=7)$ \\
\hline
\end{tabular}

\section{Experimental Groups}

\begin{tabular}{|c|c|c|}
\hline $\begin{array}{l}\text { Sodium Thiosulphate } \\
\text { group } 4 \quad(n=21)\end{array}$ & $\begin{array}{l}\text { Sodium Ascorbate } \\
\text { group } 5(n=21)\end{array}$ & $\begin{array}{c}\text { Rosemary Extract } \\
\text { group } 6(n=21)\end{array}$ \\
\hline Subgroup 4 a $(n=7) 3 \operatorname{mins}$ & Subgroup $5 \mathrm{a}(\mathrm{n}=7) 3 \mathrm{mins}$ & Subgroup 6 a $(n=7) 3$ mins \\
\hline Subgroup 4 b ( $\mathrm{n}=7) 5 \mathrm{mins}$ & Subgroup $5 \mathrm{~b}(\mathrm{n}=7$ ) 5mins & Subgroup $6 \mathrm{~b}(\mathrm{n}=7) 5 \mathrm{mins}$ \\
\hline Subgroup 4 c $(n=7) 10 \mathrm{mins}$ & Subgroup $5 \mathrm{c}(\mathrm{n}=7) 10 \mathrm{mins}$ & Subgroup $6 \mathrm{c}(\mathrm{n}=7) 10 \mathrm{mins}$ \\
\hline
\end{tabular}

Table 2: Comparison of the mean values between the groups

\begin{tabular}{|c|c|c|c|c|c|c|c|c|c|c|c|}
\hline $\begin{array}{l}\text { Negative } \\
\text { control }\end{array}$ & $\begin{array}{l}\text { Positive } \\
\text { control }\end{array}$ & saline & \multicolumn{3}{l|}{ Sodium thiosulphate } & \multicolumn{3}{l|}{ Sodium Ascorbate } & \multicolumn{3}{|c|}{ Rosemary extract } \\
\hline & & & 3 mins & 5 mins & 10 mins. & 3 mins & 5 mins & 10 mins & 3 mins & 5 mins & 10 mins \\
\hline 3.89 & 0.88 & 2.77 & 0.45 & 0.47 & 0.47 & 1.16 & 3.63 & 1.80 & 5.16 & 6.30 & 1.64 \\
\hline
\end{tabular}

Table 3: Inter Group

\begin{tabular}{|c|c|c|c|c|}
\hline Comparison & Groups & Mean & S.d. & P-value \\
\hline \multirow[t]{2}{*}{$4 a$ vs 5a } & $4 \mathrm{a}$ & 0.45 & 0.08 & $0.007 *$ \\
\hline & $5 \mathrm{a}$ & 1.16 & 0.56 & \\
\hline \multirow[t]{2}{*}{$4 \mathrm{~b}$ vs $5 \mathrm{~b}$} & $4 \mathrm{~b}$ & 0.47 & 0.04 & $0.000 *$ \\
\hline & $5 b$ & 3.63 & 1.26 & \\
\hline \multirow[t]{2}{*}{$4 \mathrm{c}$ vs $5 \mathrm{c}$} & $4 c$ & 0.45 & 0.08 & $0.000 *$ \\
\hline & $5 c$ & 1.8 & 0.121 & \\
\hline \multirow[t]{2}{*}{$5 \mathrm{a}$ vs $6 \mathrm{a}$} & $5 \mathrm{a}$ & 1.16 & 0.56 & $0.000 *$ \\
\hline & $6 \mathrm{a}$ & 5.16 & 1.08 & \\
\hline \multirow[t]{2}{*}{$5 \mathrm{~b}$ vs $6 \mathrm{~b}$} & $5 b$ & 3.63 & 1.26 & $0.040 *$ \\
\hline & $6 b$ & 6.30 & 2.87 & \\
\hline \multirow[t]{2}{*}{$5 \mathrm{c}$ vs $6 \mathrm{c}$} & $5 c$ & 1.80 & 0.12 & $0.449 * *$ \\
\hline & $6 c$ & 1.64 & 0.52 & \\
\hline \multirow[t]{2}{*}{$6 a$ vs $4 a$} & $6 \mathrm{a}$ & 5.16 & 1.08 & $0.000 *$ \\
\hline & $4 a$ & 0.45 & 0.08 & \\
\hline \multirow[t]{2}{*}{$6 \mathrm{~b}$ vs $4 \mathrm{~b}$} & $6 b$ & 6.3 & 2.87 & $0.000 *$ \\
\hline & $4 \mathrm{~b}$ & 0.47 & 0.04 & \\
\hline \multirow[t]{2}{*}{$6 \mathrm{c}$ vs $4 \mathrm{c}$} & $6 c$ & 1.64 & 0.52 & $0.000^{*}$ \\
\hline & $4 \mathrm{c}$ & 0.45 & 0.08 & \\
\hline
\end{tabular}

* Significant @ 95\% confidence level.

** Insignificant @ 95\% confidence level. 
Table 4: Intra Group

\begin{tabular}{|l|c|c|c|c|}
\hline Comparison & Groups & Mean & S.D. & P-Value \\
\hline 4a vs 4b & 4a & 0.45 & 0.08 & $0.656^{* *}$ \\
\hline & $4 \mathrm{~b}$ & 0.47 & 0.04 & \\
\hline 4b vs 4c & $4 \mathrm{~b}$ & 0.47 & 0.04 & $0.656^{* *}$ \\
\hline & 5b & 0.45 & 0.08 & \\
\hline 4c vs 4a & $4 \mathrm{c}$ & 0.45 & 0.89 & $1.000^{* *}$ \\
\hline & $4 \mathrm{a}$ & 0.45 & 0.89 & \\
\hline 5a vs 5b & 5a & 1.16 & 0.56 & $0.001^{*}$ \\
\hline & $5 \mathrm{~b}$ & 3.63 & 1.26 & \\
\hline 5b vs 5c & 5b & 3.63 & 1.26 & $0.002^{*}$ \\
\hline & $5 \mathrm{c}$ & 1.80 & 0.12 & \\
\hline 5c vs 5a & $5 \mathrm{c}$ & 1.80 & 0.12 & $0.013^{*}$ \\
\hline & $5 \mathrm{a}$ & 1.16 & 0.56 & \\
\hline 6a vs 6b & $6 \mathrm{a}$ & 5.16 & 1.08 & $0.347^{* *}$ \\
\hline & $6 \mathrm{~b}$ & 6.3 & 2.87 & \\
\hline 6b vs 6c & $6 \mathrm{~b}$ & 6.3 & 2.87 & $0.001^{*}$ \\
\hline & $6 \mathrm{c}$ & 1.64 & 0.52 & \\
\hline 6c vs 6a & $6 \mathrm{c}$ & 1.64 & 0.52 & $0.000^{*}$ \\
\hline & $6 \mathrm{a}$ & 5.16 & 1.08 & \\
\hline
\end{tabular}

* Significant @ 95\% confidence level.

** Insignificant @ 95\% confidence level.

\section{Conclusion}

Within the limitations of this invitro study, amongst the three antioxidants, use of $6 \%$ Rosemarinic acid for 3 and 5 min did significantly improved the resin cement bond strength to $\mathrm{NaOCl}$ treated dentine. Sodium thiosulphate exhibited the least reversal effect. Further research is required to determine the long term stability of the adhesive materials to dentine after the use of reducing agents.

\section{References}

1. Kakehashi S, Stanley HR, Fitzgerald RJ. The effects of surgical exposures of dental pulps in germ-free and conventional laboratory rats. Oral Surgery, Oral Medicine, Oral Pathology. 1965 Sep 30;20(3):340-9.

2. Moller AJ, Fabricius L, Dahlen G, Ohman AE, Heyden GU. Influence on periapical tissues of indigenous oral bacteria and necrotic pulp tissue in monkeys. European Journal of Oral Sciences. 1981 Dec 1;89(6):475-84.

3. 3.Sakae T, Mishima H, Kozawa Y. Changes in bovine dentin mineral with sodium hypochlorite treatment. Journal of Dental Research. 1988 Sep;67(9):1229-34.

4. Johnson WT, Noblett WC. Cleaning and shaping in: endodontics: principles and practice. Saunders, Philadelphia, PA. 2009.

5. Lai SC, Mak YF, Cheung GS, Osorio R, Toledano M, Carvalho RM, Tay FR, Pashley DH. Reversal of compromised bonding to oxidized etched dentin. Journal of Dental Research. 2001 Oct;80(10):1919-24.

6. Prasansuttiporn T, Nakajima M, Kunawarote S, Foxton RM, Tagami J. Effect of reducing agents on bond strength to NaOCl-treated dentin. dental materials. 2011 Mar 31;27(3):229-34.

7. Sooriyaarachchi M, Narendran A, Gailer J. The effect of sodium thiosulfate on the metabolism of cis-platin in human plasma in vitro. Metallomics. 2012;4(9):960-7.

8. Gomes BP, Martinho FC, Vianna ME. Comparison of $2.5 \%$ sodium hypochlorite and $2 \%$ chlorhexidine gel on oral bacterial lipopolysaccharide reduction from primarily infected root canals. Journal of Endodontics. 2009 Oct 31;35(10):1350-3.

9. Roças IN, Siqueira JF. Comparison of the in vivo antimicrobial effectiveness of sodium hypochlorite and chlorhexidine used as root canal irrigants: a molecular microbiology study. Journal of endodontics. $2011 \mathrm{Feb}$ 28;37(2):143-50.

10. 10.Santos JN, de Oliveira Carrilho MR, De Goes MF, Zaia AA, de Almeida Gomes BP, de Souza-Filho FJ, Ferraz CC. Effect of chemical irrigants on the bond strength of a self-etching adhesive to pulp chamber dentin. Journal of endodontics. 2006 Nov 30;32(11):1088-90.

11. 11.Rose RC, Bode AM. Biology of free radical scavengers: an evaluation of ascorbate. The FASEB journal. 1993 Sep 1;7(12):1135-42.

12. 12.Yiu CK, Garcia-Godoy F, Tay FR, Pashley DH, Imazato S, King NM, Lai SC. A nanoleakage perspective on bonding to oxidized dentin. Journal of dental research. 2002 Sep;81(9):628-32.

13. 13.Celik C, Erkut S, Gulsahi K, Yamanel K, Kucukesmen C. Effect of sodium ascorbate on bond strength of different adhesive systems to $\mathrm{NaOCl}$-treated dentin. Australian Endodontic Journal. 2010 Apr 1;36(1):12-8.

14. 14. Ana Carolina Pimentel Correa, Doglas Ccecchin, Jose Flavio Affonso de Almeida, Brenda Paula Figuiredo de Almeida Gomes, Alexandre Augusto Zaia and Caio Cezar Randi Ferraz, sodium thiosulphate for recovery of bond strength to dentine treated with sodium hypochlorite. Journal of Endodontics 2016; 42(2) 1-5.

15. 15.Ozturk B, Ozer F. Effect of $\mathrm{NaOCl}$ on bond strengths of bonding agents to pulp chamber lateral walls. Journal of Endodontics. 2004 May 31;30(5):362-5.

16. 16.Weston $\mathrm{CH}$, Ito $\mathrm{S}$, Wadgaonkar B, Pashley DH. Effects of time and concentration of sodium ascorbate on reversal of $\mathrm{NaOCl}$-induced reduction in bond strengths. Journal of Endodontics. 2007 Jul 31;33(7):879-81.

17. 17.da Cunha LF, Furuse AY, Mondelli RF, Mondelli J. Compromised bond strength after root dentin 
deproteinization reversed with ascorbic acid. Journal of Endodontics. 2010 Jan 31;36(1):130-4.

18. 18. Khoroushi M, Kachuei M. Pull-out bond strength of a self-adhesive resin cement to $\mathrm{NaOCl}$-treated root dentin: effect of antioxidizing agents. Restorative dentistry \& Endodontics. 2014 May 1;39(2):95-103.

19. 19. Ishizuka T, Kataoka H, Yoshioka T, Suda H, Iwasaki $\mathrm{N}$, Takahashi $\mathrm{H}$, Nishimura F. Effect of NaOcl treatment on bonding to root canal dentin using a new evaluation method. Dental materials journal. 2001;20(1):24-33.

20. 20. Islam MS, Hiraishi N, Nassar M, Sono R, Otsuki M, Takatsura T, Yiu C, Tagami J. In vitro effect of hesperidin on root dentin collagen and de/remineralization. Dental materials journal. 2012;31(3):3627.

21. 21. Islam S, Hiraishi N, Nassar M, Yiu C, Otsuki M, Tagami J. Effect of natural cross-linkers incorporation in a self-etching primer on dentine bond strength. Journal of dentistry. 2012 Dec 31;40(12):1052-9.

22. 22. Park JY, Kwon TY, Kim YK. Effective application duration of sodium ascorbate antioxidant in reducing microleakage of bonded composite restoration in intracoronally-bleached teeth. Restorative dentistry \& endodontics. 2013 Feb 1;38(1):43-7.

23. 23. Apak R, Güçlü K, Özyürek M, Bektas, oğlu B, Bener $\mathrm{M}$. Cupric ion reducing antioxidant capacity assay for food antioxidants: vitamins, polyphenolics, and flavonoids in food extracts. Advanced Protocols in Oxidative Stress I. 2008:163-93.

24. 24. Chipault JH, Mizuno GR, Hawkins JM, Lundberg WO. The antioxidant properties of natural spices. Journal of Food Science. 1952 Jan 1;17(1-6):46-55.

25. 25. Chipault JR, Mizuno GR, Lundberg WO. Antioxidant Properties Of Spices In Oil-In-Water Emulsions. Journal of Food Science. 1955 Sep 1;20(5):443-8.

26. 26. Aruoma OI, Cuppett SL, editors. Antioxidant methodology: in vivo and in vitro concepts. The American Oil Chemists Society; 1997.

27. 27. Srinivas Panchianya, Manan Pathak Lekha S, Srirekha A, Jayakumar T. Swetha R.S. Proanthocyanidine extract as a neutralizer for sodium hypochlorite-a laboratory study. Research desk, 2014,3(2)466-470.

28. 28. Jayashree Hegde, Kusum Bashetty, Krishna kumar, Utsav Gulati. Quantity of sodium thiosulphate required to neutralize various concentrations of sodium hypochlorite. Asian J Pharm. Hea Sci Jul-Sep 2012:12(3)390-93. 